\title{
Mezigenerační solidarita ve stárnoucí společnosti
}

\section{Intergenerational Solidarity in Ageing Society}

\author{
Marcela Petrová Kafková
}

\begin{abstract}
This paper focuses on the issue of intergenerational solidarity in the contemporary Czech society from the perspective of values and norms. It concentrates on normative solidarity in the parent adult child relationship, i.e. on mutual expectations of responsibility and on the norms determining the importance of family values. Due to population ageing the important question whether there is agreement among generations on the degree and existence of intergenerational obligations turns up, mainly whether seniors' expectations are not considerably different from the conception of the youngest generation. The factors affecting the degree of intergenerational solidarity are being searched for. The search is based on a data analysis from European Value Study (EVS) which surveyed values in 1991, 1999 and 2008. Due to the longitudinal nature of the data not only attitudes of seniors and the youngest generations are compared but also their change in the course of time. Lastly the position of the Czech Republic among other European countries is looked into.
\end{abstract}

KEY WORDS ageing, active ageing, Czech Republic, family values, felt obligation, intergenerational solidarity, parent-child relations

\section{Úvod}

Stárnutí populace, které $\mathrm{v}$ naší společnosti probíhá, přináší kromě mnoha jiných důsledků i proměnu vztahů v rodině. Významné prodloužení střední délky života vedlo k tomu, že etapa současné koexistence dvou dospělých generací se výrazně prodloužila. Stein a kol. (1998) uvádějí, že dospělí jedinci mohou v současnosti prožít přibližně půl století soužití se svými rodiči. Poprvé v historii tak pravděpodobně prožijeme více let jako dospělí jedinci s žijícími rodiči než jako na nich závislé děti (tamtéž). Toto výrazné prodloužení vzájemné koexistence dvou dospělých generací znamená zásadní proměnu vztahu rodičů a jejich dospělých dětí. Přestože jsou často slyšet pesimistická prohlášení o krizi rodiny a úpadku rodinné solidarity, zůstává rodina pro jedince nejen ve vyšším věku zásadním zdrojem podpory a pomoci (v českém prostředí vysokou intenzitu mezigenerační pomoci prokázali například Vidovićová a Rabušic 2003, Vohralíková a Rabušic 2004, Sýkorová 2007). S mezigenerační podporou koneckonců počítá i klíčový vládní dokument Kvalita života ve stáří.

Sociální studia. Fakulta sociálních studií Masarykovy univerzity, 4/2010. S. 63-84. ISSN 1214-813X.

Výzkum tvořící základ této stati byl finančně podpořen Grantovou agenturou České republiky, projekt č. 403/08/0999 „Hodnotové proměny v ČR 1991-2008 v evropském kontextu“. 
Národni program př́pravy na stárnutí na obdobi 2008-2012 (2008) věnující se stárnutí české populace.

Mezigeneračním vztahům na úrovni praktické pomoci či materiální podpory je věnována $\mathrm{v}$ českém prostředí značná pozornost,$^{2} \mathrm{v}$ tomto textu se na vztah rodič-dospělé dítě podívám optikou norem a hodnot. Sdílím totiž přesvědčení, ,že hodnoty indikují preference, které lidé sdílejí pro určitý typ výsledků ve svém životě a pro určitý typ chování“ (Ball-Rokeach a Loges in Rabušic 2001: 10). Nebudu se tedy zabývat kvalitou vzájemného vztahu, druhy vzájemné pomoci ani frekvencí kontaktu. Vztahy dospělých dětí a jejich rodičů jsou velmi individuální záležitostí a je velmi těžké zevšeobecnit, nakolik jsou idylické, harmonické či konfliktní. Zaměřím se proto na některé normy regulující vztah rodičů a dětí a soustředím se zejména na nalezení faktorů regulujících normy vázané ke vztahu dětí $\mathrm{k}$ rodičům a na proměnu těchto norem v posledních dvou desetiletích. Z makrospolečenského pohledu stárnoucí společnosti, která má opatřeními sociální politiky zajištovat péči o seniory a také vytvářet nejrůznější podpůrné instituce, představují normy podstatný kontext. Budu tedy také zjišt'ovat, zda v české populaci existuje určitá míra názorové shody generací na miře či existenci mezigeneračních závazků - to znamená, zda děti pocit’ují odpovědnost a závazky ke svým rodičům, a naopak zda rodiče pocitují odpovědnost a povinnosti viči svým dospělým dětem. Pro ilustraci pozice české populace v evropském kontextu srovnám její postoje k normativní solidaritě s dalšími evropskými zeměmi.

V ohnisku mé pozornosti budou především představy české seniorské populace, kterou s ohledem na stále nízký věk odchodu do důchodu definuji jako osoby šedesátileté a starší. ${ }^{3} \mathrm{~K}$ zodpovězení výzkumných otázek mi poslouží data z Evropského výzkumu hodnot (European Values Study, EVS), která máme pro Českou republiku k dispozici pro roky 1991, 1999 a 2008 (blíže o tomto výzkumu viz editorial tohoto čísla). Longitudinální povaha dat umožní nejen srovnat postoje seniorů s postoji mladších generací, ale i vysledovat jejich proměnu v čase.

\section{Proměna rodiny}

Podoba vztahů mezi jednotlivými generacemi se v posledních desetiletích výrazně proměnila. Jednou z významných prríčin této proměny je stárnutí populace. Demografická struktura rodiny se proměňuje $\mathrm{z}$ podoby pyramidy do podoby bidla (beanpole), tedy do podlouhlého úzkého tvaru. Graficky tak ztvárňuje situaci, kdy vedle sebe žije více generací, každá však má méně př́íslušníků (Bengtson 2001, Bengtson a Martin 2001). Dalšími příčinami proměny mezigeneračních vztahů jsou nízká porodnost, nárůst dlouhověkosti, vysoká rozvodovost a zvyšující se rozrůzněnost rodinných forem. Především prodloužení délky

Kromě výše zmíněných studií se mezigenerační solidaritou pomocí kvalitativní optiky zabývá i Přidalová (2007).

3 I přes zvyšující se hranici důchodového věku byl průměrný věk odchodu z trhu práce v České republice $\mathrm{v}$ roce 2008 pouhých 60,6 let (Eurostat 2010). Hranice 60 let se proto zdá být v tomto kontextu vhodnější než také velmi často použivané vymezení 65 let. Hranici 60 let používá i Světová zdravotnická organizace (WHO 2002). 
společného života a vysoká míra rozvodovosti v západních společnostech vedly Bengtsona (2001) k přesvědčení, že v rodinném životě narůstá význam mezigeneračních vztahů a dochází $\mathrm{k}$ oslabení nukleární podoby rodiny, fungující tak, jak nám ji nastínil Parsons (1955), který nukleární rodinu chápal jako relativně uzavřený systém s omezenými a nevýznamnými vazbami na širší rodinu. Prarodiče a další příbuzní jsou dle Bengtsona (2001) stále důležitější pro zajištění základních funkcí rodiny, at’ už na úrovni ekonomické či emocionální podpory.

Významnou vazbu nukleární rodiny na širší rodinu (především na rodiče) už ukázaly empirické výzkumy ze 60. let (např́iklad Willmott a Young 1960, Townsend 1957 či Rosser a Harris 1965). Studie převážně z Velké Británie zjistily existenci významné mezigenerační podpory, a to zejména ve dvou životních obdobích. Nejdříve při etablování mladé rodiny (při narození dítěte, hledání zaměstnání) a později, když prarodiče zestárnou, dostává se jim silné podpory od střední generace. V českém prostředí není možné význam mezigenerační podpory zejména ve směru od nejstarší generace k mladším opomíjet, prostředí socialistického režimu v minulosti zvýšilo závislost mladé rodiny na vlastních rodičích. Starší generace hrály významnou roli nejen při zajištění bydlení nové rodiny, ${ }^{4}$ ale zejména ženy byly výrazně zapojeny do výchovy a péče o vnoučata (Možný 1991, 1999). Toto zapojení přitom bylo do velké míry „samozřejmé“. Možný (2004) dokonce mluví o celoživotní rodičovské roli, zejména žen, která nekončí dospělostí vlastních dětí, ale pokračuje při výchově vnoučat. Celkově pak hodnotí úroveň mezigenerační solidarity v české společnosti jako značně vysokou.

Rodinnou solidaritu tedy není možné striktně omezit hranicí manželský pár a nedospělé děti. Se stále se zvyšující diverzitou rodinných forem se omezení zájmu výzkumníků pouze na nukleární rodinu ukazuje jako zcela nedostatečné a nezachycující širokou škálu různě intenzivních vazeb na další generace a širší př́ibuzenstvo. Na potřebu porozumět více rodinným vztahům za hranicemi nukleární rodiny a zejména vztahům mezigeneračním v českém prostředí upozorňuje Sýkorová (2009). Teoretické ukotvení pro studium otázky rodinné odpovědnosti poskytli Bengtson a Roberts (1991), ${ }^{5}$ kteří rozeznávají šest dimenzí mezigenerační solidarity. V tomto textu se budu věnovat pouze jedné z nich, a to solidaritě označované jako normativní, tedy normám či očekáváním závazku vůči rodině. Přestože Bengtson a Roberts (tamtéž) zkoumali pocit závazku dospělých dětí vůči stárnoucím rodičům, nemůžeme opomenout ani opačný směr poskytování podpory. Bengtson (2001: 8) dokonce mluví o tzv. intergenerational stake, tedy o vyšší solidaritě rodičů než dětí, kdy rodiče investují zejména nemateriální, psychosociální zdroje ve vyšší míře než mladší generace. Podpora plynoucí ve směru

4 Aktuální data Eurobarometru (Intergenerational 2009) však ukazují, že s výrokem „finanční pomoc rodičů a prarodičů je pro mladé důležitá při vytváření vlastní domácnosti“ Češi souhlasí nejméně po Nizozemcích a Dánech.

5 Jak upozorňuje Sýkorová (1996: 60), koncept mezigenerační solidarity integruje teorie equity, exchange, obligatory $i$ attachment, a je tak vhodný pro výzkumnou práci. Sám Bengtson (Bentson a Martin 2001: 213) upozorňuje, že konflikt tvoří neoddělitelnou součást mezigeneračních vztahů stejně jako solidarita. Nejsou to přitom dva protikladné póly, mezigenerační vztah může mít malou solidaritu i konflikt, stejně jako velkou solidaritu i velké konflikty. 
od starší generace k mladší tedy není jen specifikem české společnosti. Z tohoto důvodu se budu věnovat jak vztahu rodičů $\mathrm{k}$ dětem, tak dětí k rodičům.

Sýkorová (2007) ukazuje, že pomoc dětí stárnoucí generaci rodičů v seniorském věku je v české populaci běžná a vzniká právě s objevením se této potřeby. Dle aktuálních potřeb seniora se pomoc stává intenzivnější a proměňuje se. Zjištění autorky (tamtéž) o naplnění potřeby pomoci v situaci, kdy se objeví, koresponduje s konceptem podmíněné směny (contingent care). Eggerbeen a Davey (1998) dokazují podmíněnost prŕibuzenské pomoci životními událostmi, podpora se tedy aktivuje životními krizemi a potřebou pomoci. Relativně málo frekventované vztahy dospělých dětí a jejich rodičů se tak znovu stávají častější s tím, jak rodiče stárnou. Potřeba péče o stárnoucí rodiče postupně zvyšuje frekvenci kontaktu a mění jeho povahu. Vidovićová a Rabušic (2003) zjistili, že ve střední generaci (ve věku 45-59 let) se 64\% jedinců se svými rodiči setkává minimálně jednou týdně. Zkušenost s domácí péčí o nesoběstačného seniora má však pouze čtvrtina českých domácností (Jeřábek 2009: 251). Stále častěji také potřeba péče o nesoběstačného seniora nezasahuje do života ve středním věku, ale týká se až mladších seniorů (jedinců v třetím věku, tedy přibližně ve věku $60+$ ), kteří pečují o své osmdesátileté a starší rodiče. Senioři tak nemusí být jen př́ijemci péče, ale mohou být také její poskytovatelé.

Povaha mezigenerační solidarity se ve všech euro-amerických společnostech mění společně s proměnou rodiny a životního běhu jedince. Česká společnost navíc ještě stále prochází celkovou transformací, a tedy i proměnnou hodnot, bez které by společenská změna nebyla možná (Rabušic 2001). Informace o budoucím nárůstu počtu seniorů v české populaci jsou často provázeny zmínkami o možném vzniku mezigeneračního konfliktu. Všechny tyto výše zmiňované změny společnosti i rodiny mě vedou k otázce, jaká je podoba solidarity rodičů a dětí na úrovni hodnot? Ptám se na existenci a intenzitu normativní solidarity, tedy na vzájemná očekávání odpovědnosti a závazku dětí a rodičů a také na normy určující důležitost rodinných hodnot (Bengtson 2001: 8). ${ }^{6}$ Jinými slovy se ptám, zda mají děti povinnost pečovat o své rodiče a rodiče závazek pečovat o své děti. Jak je pro nás důležitá rodina? A musíme mít ke svým rodičům úctu? Všechny tyto otázky, které v operacionalizované podobě klade opakovaně výzkum EVS, jsou pro mne empirickými indikátory normativní dimenze solidarity. ${ }^{7}$

Výzkumy ukazují, že mezigenerační solidarita je ovlivněna mnoha socio-demografickými charakteristikami dospělých dětí i jejich rodičů. Jednou z nejdůležitějších charakteristik ovlivňujících variabilitu v mezigeneračních vztazích je gender. Ženy jsou častěji než

$6 \quad$ V jiném textu Bentsona (Bentson a Roberts 1991: 857) je normativní solidarita definována jako síla závazku vykonávat rodinné role a plnit (uspokojovat) rodinné povinnosti. $\mathrm{V}$ tomto př́padě zvolili autoři jako empirické indikátory míru důležitosti rodiny a mezigeneračních rolí a míru intenzity závazků, povinností dospělých dětí.

7 Ve všech třech vlnách výzkumu EVS se opakují tři otázky, které Bengtson (1991 a 2001) chápe jako indikátory normativní dimenze mezigenerační solidarity. Jsem si vědoma toho, že pro analýzu vztahu dospělých dětí k rodičům by bylo vhodné využít ještě jiné otázky než ty, které se zaměřují na úctu $\mathrm{k}$ rodičům. Na místě by byla otázka, která by se spíš dotazovala na pocit odpovědnosti vůči rodičům. Ta ale byla použita až v roce 2008 , a nebylo by tedy možné provést srovnání postojů se situací v letech 1991 a 1999. 
muži v úzkém kontaktu se svými rodiči a také o ně častěji pečují (Schans a Komter 2010). Tošnerová (2001) uvádí, že v českém prostředí jsou tři čtvrtiny pečujících osob ženy, nejčastěji dospělé dcery. I další výzkumy ukazují větší zastoupení žen v poskytování praktické pomoci rodičům. Na úrovni hodnot však není větší role žen tak jednoznačná a například Finch a Mason (1993: 17) zjistily, že ve Velké Británii není rozdíl v pohledu mužů a žen na normy a hodnoty týkající se rodinné odpovědnosti. Otázce, zda je to možné tvrdit i o české společnosti, se budu věnovat níže.

Vzájemná závislost dětí a rodičů je ovlivněna jejich biografií a je intenzivnější v několika životních obdobích zmíněných výše. Rozdílný pohled dětí a rodičů na to, zda jsou děti zavázané respektovat rodiče či zda jim mají oplácet péči, mohou být zdrojem konfliktu mezi generacemi. Ve stáŕí navíc často dochází $\mathrm{k}$ napětí mezi klesající autoritou jedince, s tím jak ztrácí svou soběstačnost, a stoupající autoritou dětí v jeho životě (Gaalen a Dykstra 2006). Senioři jsou navíc často konzervativnější než mladší jedinci a jsou chápáni jako nositelé „tradičních hodnot". Kromě genderu a věku budu zkoumat vliv bydliště, vzdělání, rodinného stavu a religiozity jedince na úroveň jeho mezigenerační solidarity.

\section{Odpovědnost dětí vưči rodičưm a rodičů vưči dětem}

Pouhý pohled na deskriptivní statistiky z dat EVS ukazuje, že vnímání normativní solidarity se $\mathrm{v}$ české společnosti $\mathrm{v}$ posledních dvaceti letech proměnilo. Zatímco $\mathrm{v}$ roce 1991 souhlasilo $81 \%$ českých občanů s výrokem, že děti musí své rodiče ctít a vážit si jich bez ohledu na jejich přednosti a nedostatky, v roce 2008 už to bylo jen $65 \%$ (Rabušic a Hamanová 2009). ${ }^{8}$ Navíc se ukazuje, že souhlas s výrokem stoupá s rostoucím věkem respondenta (viz graf 1$){ }^{9} \mathrm{~K}$ poklesu normativní solidarity došlo i v opačném směru, tedy ve směru odpovědnosti rodičů vůči dospělým dětem. V roce 1991 bylo $65 \%$ respondentů přesvědčeno, že rodiče mají povinnost udělat pro své děti vše, v roce 2008 to bylo $53 \% .{ }^{10}$ První

8 Respondenti vybírali ze dvou nabízených výroků ten, se kterým spíše souhlasili. První výrok zněl: „Bez ohledu na jejich přednosti a nedostatky musíme mít své rodiče rádi a vážit si jich.“ Druhý: „Člověk není povinen ctít a milovat své rodiče, kteří si to nezaslouží svým chováním a postoji.“

9 Testován byl i vztah mezi nutností ctít rodiče a vzděláním, bydlištěm, soužitím s partnerem a počtem dětí respondenta. Jako statisticky nevýznamný se ukázal vliv vzdělání a soužití s partnerem (hodnoty Spearmanova rho byly ve všech vlnách výzkumu nižší než 0,1 ). Vztah počtu dětí se ukázal jako zdánlivý, protože do vztahu intervenuje věk respondenta. V roce 2008 se objevil i slabý vliv velikosti bydliště (Spearmanovo rho 0,11 ), kdy se zvětšujícím se místem bydliště klesá přesvědčení respondenta o nutnosti ctít rodiče. V předchozích vlnách výzkumu však byl vztah nevýznamný (Spearmanovo rho mělo v obou případech hodnotu 0,07 ).

10 Respondenti volili jeden ze dvou protikladných výroků, nebo mohli spontánně nesouhlasit ani s jedním. Přesné znění otázky bylo následující: „Který z následujících výroků nejlépe vystihuje Váš názor na odpovědnost rodičů vůči dětem? 1) Povinností rodičů je udělat to nejlepší pro své děti i na úkor svého vlastního prospěchu. 2) Rodiče mají svůj vlastní život a neměl by po nich nikdo chtít, aby se obětovali ve prospěch svých dětí.“ 
pohled na data tedy naznačuje celkový úbytek mezigenerační solidarity, při další analýze zjistíme velkou věkovou ${ }^{11}$ a genderovou variabilitu odpovědí.

Graf 1: Úcta dětí k rodičům: Podíl respondentů souhlasících s výrokem, že rodiče musíme ctít, i když si to nezaslouží ( $\vee \%)$

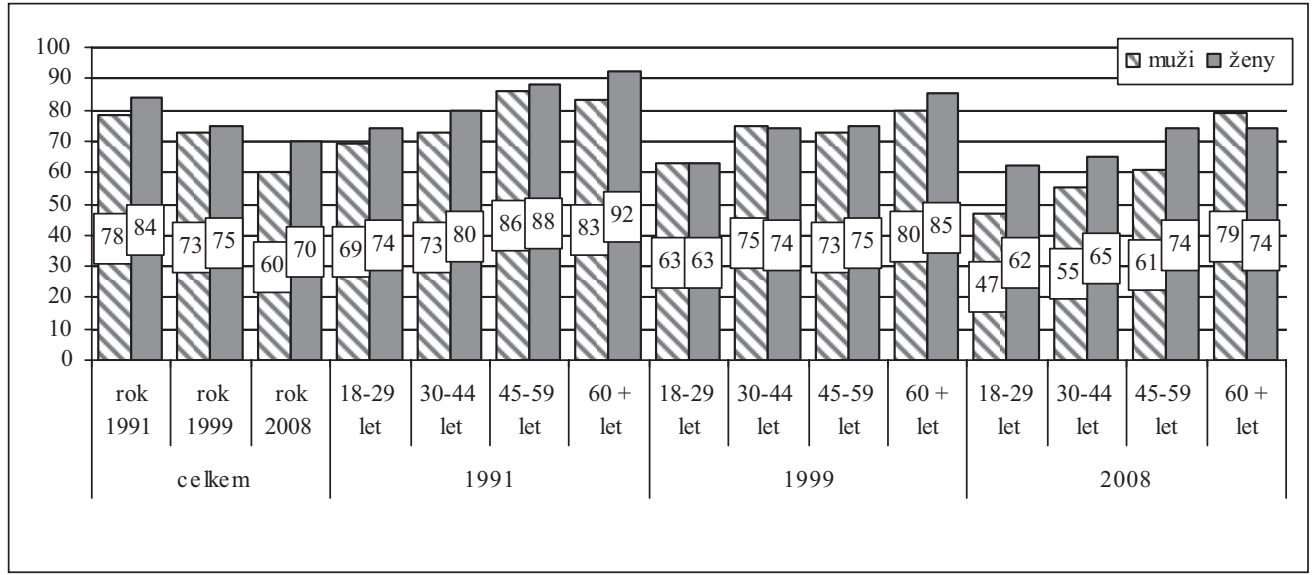

Zdroj: EVS 1991, 1999 a 2008, vlastní výpočet.'

Poznámka: rok $1991 \mathrm{n}=2057$, rok $1999 \mathrm{n}=1819$, rok $2008 \mathrm{n}=1609$.

Muži obecně deklarují nižší souhlas s povinnosti ctít rodiče než ženy. ${ }^{12}$ Genderové rozdíly se však liší v závislosti na věku respondenta a jsou různě silné v jednotlivých výzkumných vlnách. U žen dochází od roku 1991 k postupnému poklesu přesvědčení o nutnosti ctít rodiče, a to ve všech generacích. Vliv věku se u žen postupně snižuje, přesto je stále patrný nárůst souhlasu s výrokem ve vyšším věku. V současnosti však nemůžeme mluvit o odlišném postoji seniorek, protože jejich postoj se shoduje s postojem střední generace žen (ve věku 45-59 let), v obou skupinách byl souhlas s nutností ctít rodiče 74\%. Nejméně souhlasí nejmladší skupina žen (ve věku 18-29 let), a to z $62 \%$.

Mezi muži není pokles souhlasu s nutností ctít rodiče v čase postupný. Mezi roky 1991 a 1999 došlo jen k velmi malému poklesu, a to zejména v nejmladší generaci (18-29letých), o to výraznější je však pokles v současnosti. Výrazný pokles se přitom týká všech generací neseniorského věku, míra souhlasu tak v současnosti variuje mezi $47 \%$ u nejmladších mužů po 61 \% u 45-59letých. Muži mladší 60 let jsou tak o povinnosti ctít rodiče přesvědčeni méně než ženy a dokonce i méně než nejmladší skupina žen. Genderové rozdíly se tedy v současnosti v porovnání se situací v devadesátých letech výrazně prohloubily. Přestože u mužů

11 Vzájemná korelace věku a nutnosti ctít rodiče v roce 2008 zesílila a Spearmanovo rho mělo hodnotu $0,2, \mathrm{v}$ roce 1991 to bylo 0,16 a v roce 19990,17 .

12 Korelace odpovědnosti dětí vůči rodičům a pohlaví respondenta je v roce 2008 nejsilnější (hodnota Spearmanova rho je 0,11$)$. V roce 1991 byla vzájemná korelace obou proměnných 0,08 a v roce 1999 byla nejslabší $(0,03)$. Korelace jsou natolik nízké, že je věcně musíme považovat za nulové. 
i žen dochází $\mathrm{k}$ poklesu souhlasu s přesvědčením o nutnosti ctít rodiče, je tento pokles silnější u mužů než u žen.

Čím je však způsoben výrazný rozdíl mužů a žen v přesvědčení o povinnosti ctít rodiče? Dle „teorie závazku“ (obligation theory, Stein a kol. 1998) je př́činou pocitu odpovědnosti $\mathrm{k}$ rodičům subjektivní pocit povinnosti dětí splatit rodičům dluh za péči a výchovu. Stein s kolegy (tamtéž) přitom zjistila, že ženy tuto odpovědnost pocit’ují silněji než muži, pokud mají však jen jednoho rodiče, mají větší pocit odpovědnosti obě pohlaví. Hlavními nositelkami mezigenerační solidarity v rodině jsou totiž stále ženy (Finch 1989). Nárůst rozdílů mezi pohlavími, který je nejvýraznější v nejmladší zkoumané generaci do 29 let, se však neshoduje s mým předpokladem o sbližování postojů mužů a žen. Nesouhlasí také se zjištěním Finch a Mason (1993), že na úrovni norem nejsou v mezigenerační pomoci významné rozdíly mezi pohlavími, ale projevují se až při realizaci konkrétní pomoci.

Zatím jsem se věnovala především neseniorské populaci. Jak se však proměnil postoj seniorů v této otázce? Senioři souhlasí s povinností ctít rodiče z celé české populace nejsilněji, i u nich však došlo k proměně. V roce 1991 vyjádřilo svůj souhlas s výrokem $89 \%$ $\mathrm{z}$ nich, zatímco $\mathrm{v}$ roce 2008 pouze $76 \%{ }^{13} \mathrm{~V}$ seniorském věku se také potřeba podpory či nějaké formy pomoci stává aktuálnější. Vysoká solidarita seniorské populace se tak jeví jako logická. Z Grafu 1 je přitom patrné, že pokles je nesen především ženami. ${ }^{14}$ Ze seniorek souhlasilo na začátku devadesátých let $92 \%$, v roce 2008 již jen $74 \%$. U seniorů se však postoj k úctě vůči rodičům nezměnil (v roce 1991 souhlasilo $83 \%$, v roce $199980 \%$ a v roce $200879 \%){ }^{15}$ Seniorky tedy v roce 1991 v porovnání s ostatní českou populací vyjadřovaly velmi vysokou úctu $\mathrm{k}$ rodičům, $\mathrm{v}$ současnosti se jejich postoj přibližil mladší generaci. U mužů však věk ovlivňuje postoj k rodičům stále silněji, a zatímco u nejmladší generace je souhlas nižší než $50 \%$, v seniorské populaci je více než tříčtvrtinový. Tak výrazný rozdíl postojů mezi různými generacemi českých mužů nabízí otázku, zda mezi generacemi nemůže dojít $\mathrm{k}$ rozporu. Právě konfliktnost norem je totiž dle teorie mezigenerační ambivalence (intergenerational ambivalence) Lueschera a Pillemera (1998) jedním ze tř́ zdrojů této mezigenerační ambivalence. Dalšími jsou rozpor mezi osobní autonomií a závislostí a rozpory vyplývající právě ze solidarity.

Vyšší solidarita seniorů je vysvětlitelná i jejich vyšší religiozitou. Lidé, kteří považují náboženství ve svém životě za důležité, jsou častěji přesvědčeni o nutnosti ctít rodiče, ${ }^{16}$ koneckonců přikázání úcty $\mathrm{k}$ rodičům je součástí Desatera. Přitom náboženství má největší význam právě pro seniorskou populaci, zejména pro ženy-seniorky. ${ }^{17}$ Výše zmíněné rozdíly

13 Výsledek pro rok 2008 se statisticky signifikantně odlišuje od obou předchozích vln (Sig. F = 0,00). A postoje seniorů a seniorek se statisticky významně odlišují pouze v roce 1991.

14 Rozdíly mezi jednotlivými vlnami výzkumu jsou v podsouboru žen statisticky signifikantní (Sig. $\mathrm{F}=0,00)$.

15 Rozdíly mezi jednotlivými vlnami nejsou v podsouboru mužů statisticky signifikantní (Sig. $\mathrm{F}=0,6)$.

16 Korelace odpovědnosti dětí vůči rodičům a významu náboženství v životě měla dle Spearmanova rho $\mathrm{v}$ roce 2008 hodnotu 0,22 , v roce 19990,15 a v roce $19910,13$.

17 Celkově nevnímá česká populace náboženství jako důležité. V roce 2008 ho za důležité (velmi nebo dosti důležité) označilo $19 \%$ populace, v roce 1999 20\% a v roce $199128 \%$. V seniorské 
normativní solidarity jsou tedy vysvětlitelné různým významem náboženství v jejich životech. Zdá se, že $\mathrm{v}$ tomto př́padě je změna postoje nesena mladou generací a předpokládám proto, že i další generace bude $\mathrm{v}$ seniorském věku vyjadřovat nižší povinnost úcty k rodičům než současná generace seniorů. Přesto je patrné, že rozdílný postoj mladších a starších generací v této dimenzi solidarity existuje.

Jak už bylo zmíněno, došlo od počátku devadesátých let minulého století nejen $\mathrm{k}$ poklesu souhlasu s tímto aspektem rodinných hodnot, ale i $\mathrm{k}$ poklesu $\mathrm{v}$ opačném směru, tedy $\mathrm{s}$ odpovědností rodičů vůči dětem. Souhlas s výrokem, že rodiče musí udělat pro své děti vše i na úkor vlastního prospěchu, se nezvyšuje lineárně se zvyšujícím se věkem respondenta, jak bychom mohli očekávat, ale vztah je složitější. Stejně jako u předchozí otázky se v současnosti nově objevily výrazné rozdíly mezi muži a ženami. ${ }^{18}$ Tyto rozdíly jsou však patrné jen v jednotlivých věkových skupinách, celkově se pohled mužů a žen na odpovědnost rodičủ vůči dětem neliší (rozdíly nejsou statisticky významné). S tím, že rodiče musí pro své děti udělat vše, souhlasí o něco více než polovina české populace. ${ }^{19}$ Největší rozdíl v pohledu mužů a žen se objevil mezi 30-44letými v roce 2008 (viz graf 2). Zatímco ženy v tomto věku podporují odpovědnost rodiču za děti nejméně ( $45 \%$ ), muži naopak deklarují vysokou míru odpovědnosti rodičů vůči dětem (59\%). Výsledek je o to překvapivější, že v tomto věku má velká většina populace zodpovědnost za nezletilé děti. Můžeme se jen domnívat, že nízký souhlas žen s povinností rodičů udělat pro své děti vše je odrazem toho, že nechtějí být vnímány jen jako matky. Otázkou však je, zda se v jejich úvahách jedná o solidaritu vůči vlastním dětem či jejich stárnoucích rodičů $\mathrm{k}$ nim. Výsledek proto není možné jednoznačně vysvětlit a zasloužil by si hlubší zkoumání.

Stejně jako se neliší v celkovém pohledu postoj mužů a žen na pomoc rodičů dětem, tak se významně neliší postoj českých seniorů a seniorek, kteří se s pomocí rodičů dětem ztotožňují nejsilněji. I v této věkové skupině však přesvědčení o nutnosti obětování se dětem zesláblo. Zatímco v roce 1991 bylo o povinnosti rodičů udělat pro své děti vše přesvědčeno $72 \%$ české seniorské populace, $\mathrm{v}$ současnosti je to $57 \% .^{20}$ Přes stále vysoké hodnoty této složky solidarity $\mathrm{v}$ celé populaci a především mezi seniory je patrná významná proměna vztahu rodičů $\mathrm{k}$ dětem $\mathrm{v}$ posledních dvou desetiletích.

populaci to však v roce 2008 bylo $31 \%$ (v roce $199936 \%$ a v roce 1991 celých $50 \%$ ). V celé populaci přitom udává důležitost náboženství v životě více žen než mužů ( $21 \%$ žen a $11 \%$ mužů) a tento rozdíl se drží ve všech věkových skupinách.

18 Kromě korelace $\mathrm{s}$ věkem a pohlavím respondenta bylo testováno, zda vztah rodičů k dětem neovlivňuje vzdělání a bydliště respondenta, jeho soužití s partnerem či počet dětí, které má. U žádné z těchto proměnných však nebyla korelace statisticky významná (byla ve všech př́padech i vlnách výzkumu nižší než 0,1$)$. Velmi slabá souvislost byla nalezena v současnosti mezi důležitostí náboženství a vztahem rodičů $\mathrm{k}$ dětem: Lidé, pro které je náboženství v životě důležitější, jsou častěji přesvědčení o tom, že rodiče musí pro své děti udělat vše (korelační koeficient Spearmanovo rho měl v roce 2008 hodnotu 0,11, v roce 19990,09 a v roce 1991 0,05).

19 Korelace mezi pohlavím a odpovědností dětí vůči rodičům je statisticky nevýznamná a ve všech třech vlnách výzkumu je hodnota Spearmanova rho menší než 0,05 .

20 V roce 1999 to bylo $67 \%$. 
Graf 2: Odpovědnost rodičů vưči dětem: Podíl respondentů souhlasících s výrokem, že rodiče pro své děti musí udělat vše ( $\vee \%)$

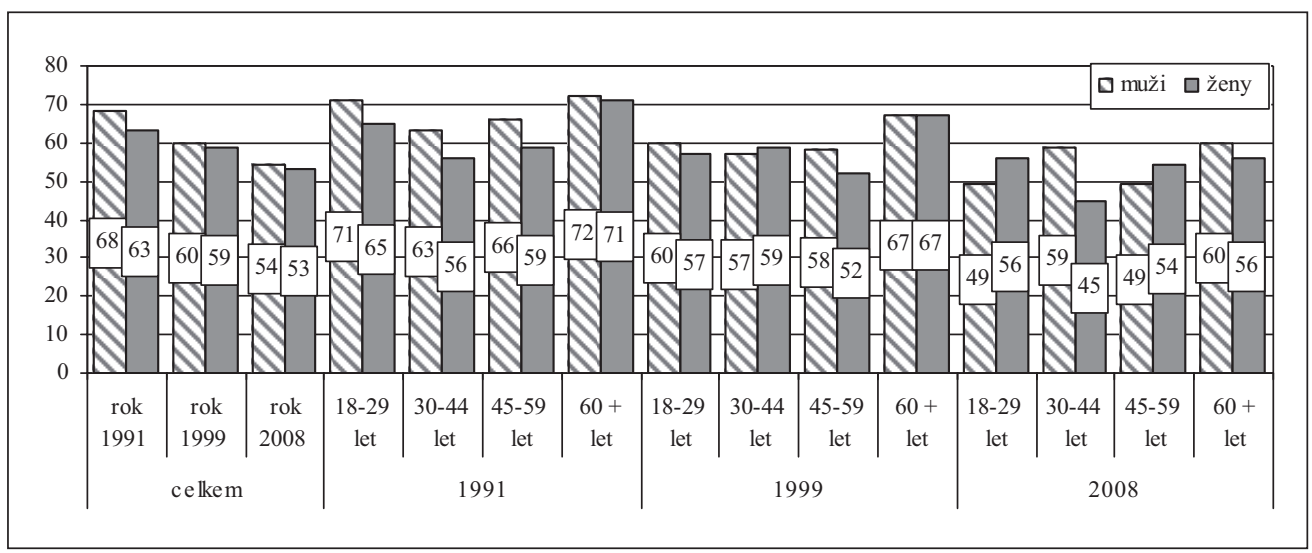

Zdroj: EVS 1991, 1999 a 2008, vlastní výpočet.

Poznámka: rok $1991 \mathrm{n}=2060$, rok $1999 \mathrm{n}=1879$, rok $2008 \mathrm{n}=1681$.

Poměrně výrazný pokles je vysvětlitelný proměnou významu širších rodinných vazeb od dob socialistického hospodaření. Původně vysoká závislost mladých lidí na rodině původu, tak jak ji popsal Možný (1991, 1999), přestává být legitimní, stejně jako „,plné obětování se mladé rodině“. Hasmanová Marhánková (2010) zjistila, že české seniorky, které velmi aktivně participující na různých volnočasových aktivitách, kladou velký důraz na to, aby jejich pomoc s péčí o vnoučata nebyla povinností, a že těmto aktivitám vyhrazují jen takovou část svého denního programu, kterou jsou samy ochotny vyčlenit. Vymezují se tak proti stereotypní představě ,hlídací babičky“. Přestože autorka ukazuje, že i v životě těchto žen hraje prarodičovství významnou roli, zdá se mně být toto silné vymezování se vůči stereotypní představě seniorek náznakem, že koncept aktivního stárnutí bývá v některých případech zjednodušován na podporu vyvázání se z veškerých závazků a prosté užívání si. Tedy v př́padě žen také vyvázání se z role babičky a pečovatelky, která byla až donedávna vnímána jako „samozřejmá“. Mediálním odrazem toho vyvázání z rolí pak může být i obraz št’astného aktivního seniora užívajícího si vysokohorskou turistiku či jiný koníček odehrávající se mimo domov. V kontextu mezigeneračních vztahů považuji za podstatné připomenout, že Světová zdravotnická organizace (WHO 2002) ve své definici aktivního stárnutí zdůrazňuje i př́nos seniorů $\mathrm{v}$ rodině a jejich participaci v rodinném životě. Tedy že aktivní stárnutí znamená především stárnutí neizolované a aktivní participaci v sociálních sítích. Pokud bychom omezili chápání konceptu aktivního stárnutí na pouhé vyvázání se z rolí, dostali bychom se do rozporu právě s jeho nejdůležitějším prvkem, tedy s podporou neizolovanosti seniorů. Není možné vyvázat se ze všech vazeb, a přitom být plně integrován do společnosti. Zdá se mně navíc kontradiktorní podporovat na jednu stranu vyvázání mladých seniorů z rolí a na druhou stranu očekávat, že v péči o starší seniory bude hrát klíčovou roli jejich rodina. Mezigenerační solidarita je totiž obvykle reciproční, i když poměr transferů nemusí být nutně 
vyrovnaný. Ačkoliv považuji koncept aktivního stárnutí za velmi užitečný, vnímám toto zjednodušování jako značně problematické.

Vrátím-li se k prezentovaným zjištěním, lze shrnout, že míra normativní solidarity vyjádřená rodinnými hodnotami v české společnosti v posledních dvou desetiletích výrazně poklesla. Nabízí se proto otázka, zda je v současnosti rodina pro Čechy méně důležitá. Výše uvedené výsledky na první pohled podporují pesimistická prohlášení o úpadku rodinných hodnot a konci rodiny. Rodina však zůstává pro Čechy v jejich životech velmi významná (viz tabulku 1). Od roku 1991 došlo jen k nepatrnému poklesu jedinců považujících rodinu ve svém životě za velmi důležitou (v roce 2008 ji takto označilo 81 \% respondentů, v roce $199985 \%$ a v roce 199186 \%). ${ }^{21}$ Opět se však výrazně liší postoj jednotlivých generací i mužů a žen.

Tabulka 1: Důležitost rodiny $\vee$ životě, dle pohlaví a věku ( $\vee \%)$

\begin{tabular}{|c|c|c|c|c|c|c|c|c|c|c|c|}
\hline & \multicolumn{5}{|c|}{ muži } & \multicolumn{5}{|c|}{ ženy } \\
\hline & & $\begin{array}{l}\text { velmi } \\
\text { důle- } \\
\text { žitá }\end{array}$ & $\begin{array}{l}\text { dosti } \\
\text { důle- } \\
\text { žitá }\end{array}$ & $\begin{array}{c}\text { ne příliš } \\
\text { dưle- } \\
\text { žitá }\end{array}$ & $\begin{array}{l}\text { vůbec } \\
\text { ne dů- } \\
\text { ležitá }\end{array}$ & $\begin{array}{l}\text { cel- } \\
\text { kem }\end{array}$ & $\begin{array}{l}\text { velmi } \\
\text { důle- } \\
\text { žitá }\end{array}$ & $\begin{array}{l}\text { dosti } \\
\text { důle- } \\
\text { žitá }\end{array}$ & $\begin{array}{c}\text { ne príliš } \\
\text { dưle- } \\
\text { žitá }\end{array}$ & $\begin{array}{l}\text { vủbec } \\
\text { ne dů- } \\
\text { ležitá }\end{array}$ & $\begin{array}{l}\text { cel- } \\
\text { kem }\end{array}$ \\
\hline \multirow{5}{*}{$\begin{array}{l}\bar{a} \\
a \\
\text { ov }\end{array}$} & 18-29 let & $74 \%$ & $20 \%$ & $6 \%$ & $0 \%$ & $100 \%$ & $87 \%$ & $12 \%$ & $0 \%$ & $1 \%$ & $100 \%$ \\
\hline & 30-44 let & $87 \%$ & $11 \%$ & $1 \%$ & $0 \%$ & $100 \%$ & $91 \%$ & $8 \%$ & $1 \%$ & $0 \%$ & $100 \%$ \\
\hline & 45-59 let & $87 \%$ & $11 \%$ & $2 \%$ & $0 \%$ & $100 \%$ & $90 \%$ & $10 \%$ & $0 \%$ & $0 \%$ & $100 \%$ \\
\hline & $60+$ let & $80 \%$ & $17 \%$ & $1 \%$ & $1 \%$ & $100 \%$ & $89 \%$ & $9 \%$ & $1 \%$ & $1 \%$ & $100 \%$ \\
\hline & celkem & $82 \%$ & $15 \%$ & $3 \%$ & $0 \%$ & $100 \%$ & $89 \%$ & $10 \%$ & $0 \%$ & $0 \%$ & $100 \%$ \\
\hline \multirow{5}{*}{$\begin{array}{l}\frac{a}{a} \\
\frac{a}{y} \\
\frac{0}{0}\end{array}$} & 18-29 let & $74 \%$ & $22 \%$ & $4 \%$ & $0 \%$ & $100 \%$ & $88 \%$ & $12 \%$ & $0 \%$ & $0 \%$ & $100 \%$ \\
\hline & 30-44 let & $78 \%$ & $19 \%$ & $3 \%$ & $0 \%$ & $100 \%$ & $94 \%$ & $6 \%$ & $0 \%$ & $0 \%$ & $100 \%$ \\
\hline & 45-59 let & $78 \%$ & $21 \%$ & $2 \%$ & $0 \%$ & $100 \%$ & $92 \%$ & $8 \%$ & $0 \%$ & $0 \%$ & $100 \%$ \\
\hline & $60+$ let & $83 \%$ & $15 \%$ & $1 \%$ & $1 \%$ & $100 \%$ & $89 \%$ & $9 \%$ & $2 \%$ & $0 \%$ & $100 \%$ \\
\hline & celkem & $78 \%$ & $19 \%$ & $3 \%$ & $0 \%$ & $100 \%$ & $91 \%$ & $8 \%$ & $1 \%$ & $0 \%$ & $100 \%$ \\
\hline \multirow{5}{*}{ 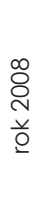 } & 18-29 let & $64 \%$ & $32 \%$ & $4 \%$ & $0 \%$ & $100 \%$ & $80 \%$ & $17 \%$ & $3 \%$ & $0 \%$ & $100 \%$ \\
\hline & 30-44 let & $83 \%$ & $16 \%$ & $2 \%$ & $0 \%$ & $100 \%$ & $91 \%$ & $8 \%$ & $1 \%$ & $0 \%$ & $100 \%$ \\
\hline & 45-59 let & $77 \%$ & $18 \%$ & $5 \%$ & $1 \%$ & $100 \%$ & $91 \%$ & $8 \%$ & $0 \%$ & $0 \%$ & $100 \%$ \\
\hline & $60+$ let & $78 \%$ & $18 \%$ & $4 \%$ & $1 \%$ & $100 \%$ & $87 \%$ & $11 \%$ & $2 \%$ & $1 \%$ & $100 \%$ \\
\hline & celkem & $74 \%$ & $22 \%$ & $4 \%$ & $0 \%$ & $100 \%$ & $88 \%$ & $10 \%$ & $1 \%$ & $0 \%$ & $100 \%$ \\
\hline
\end{tabular}

Zdroj: EVS 1991, 1999, 2008, vlastní výpočet.

Poznámka: rok $1991 \mathrm{n}=2103$, rok $1999 \mathrm{n}=1901$, rok $2008 \mathrm{n}=1807$.

Vliv věku a genderu na hodnocení významu rodiny se přitom v posledních dvaceti letech zvyšuje. ${ }^{22}$ Pro ženy všech věkových skupin je rodina důležitější než pro muže. Zatímco

21 Respondenti hodnotili důležitost rodiny ve vlastním životě na škále ,velmi důležitá, důležitá, ne př́liš důležitá a vưbec nedůležitá“. Přesné znění otázky bylo: „Prosím řekněte, pro každou z následujících skutečností, jak jsou ve Vašem životě důležité... rodina.“

22 Hodnoty Spearmanova rho pro korelaci důležitosti rodiny a pohlaví jsou 0,09 pro rok 1991, 0,18 pro rok 1999 a 0,17 v roce 2008 . Vzájemné korelace věku respondenta a důležitosti rodiny $0,04 \mathrm{v}$ roce $1991,0,06 \mathrm{v}$ roce 1999 a $0,13 \mathrm{v}$ roce 2008 . 
současní mladí muži (18-29 let) považují rodinu za velmi důležitou v $64 \%$ př́padů, ženy stejného věku v $80 \%$. Nejmladší generace přitom uvádí nejnižší význam rodiny. Generační rozrůznění významu rodiny se u žen objevilo až v roce 2008 , v devadesátých letech nebyly mezigenerační rozdíly statisticky významné. ${ }^{23} \mathrm{~V}$ současnosti je však rodina méně důležitá pro ženy do 30 let než pro ženy starší. Zdá se, že mladé ženy se tak v postoji k rodině přibližují mužům. Když vezmeme v úvahu výrazné zvýšení věku při narození prvního dítěte i odložení sňatku do vyššího věku, zdá se tato proměna velmi logická. Pro české seniory a seniorky se význam rodiny v posledních dvou desetiletích nezměnil a zůstává velmi vysoký. Zdá se však, že se význam rodiny nezvyšuje s věkem, a naopak v seniorském věku mírně klesá. Přestože tento výsledek může působit znepokojivě, nejsou rozdíly natolik významné, abychom je mohli interpretovat. Celkově si rodina v životě české populace zachovává velkou důležitost.

Nabízí se otázka, zda není míra solidarity zejména ve vyšším věku ovlivněna zdravotním stavem jedince. Špatný zdravotní stav totiž znamená závislost na pomoci a podpoře druhých, typicky především rodiny, tedy vyšší míru solidarity. Odráží se tato vyšší míra praktické solidarity (functional solidarity) i do oblasti solidarity normativní? Ve výzkumu EVS byli respondenti dotazováni na svůj subjektivní zdravotní stav, ${ }^{24}$ bohužel však pouze v letech 1991 a 2008. Údaje pro rok 1999 nám tedy chybí. Pokud se zaměříme pouze na seniorskou populaci, zjistíme, že svůj zdravotní stav považuje v současnosti za dobrý nebo velmi dobrý 34\% z nich, 44\% za ucházející a 22\% za špatný či velmi špatný. Ve srovnání se situací na začátku devadesátých let je to zlepšení. V roce 1991 vnímala jen čtvrtina seniorské populace svůj zdravotní stav jako dobrý nebo velmi dobrý, 52\% jako ucházející a $23 \%$ jako špatný či velmi špatný. Seniorky přitom uvádějí horší zdravotní stav než senioři. ${ }^{25} \mathrm{~V}$ této populaci je vliv zdravotního stavu na mezigenerační solidaritu v současnosti jasně patrný. Senioři, kteří považují svůj zdravotní stav za dobrý, jsou přesvědčeni o nutnosti ctít rodiče ze $79 \%$, ti, kteří jej považují za špatný, pak z $88 \%{ }^{26}{ }^{26}$ U žen je rozdíl ještě větší. Seniorky s dobrým zdravotním stavem souhlasí s nutností ctít rodiče v $63 \%$, ty se špatným zdravím v $83 \%$. Tato souvislost se však objevuje nově, v roce 1991 se postoj seniorů ani seniorek k úctě k rodičům v závislosti na subjektivním zdravotním stavu neměnil. ${ }^{27} \mathrm{O}$ nutnosti ctít rodiče bylo v roce 1991 přesvědčeno $92 \%$ žen a $83 \%$ mužů. Podobně začal zdravotní stav seniorů ovlivňovat i pohled na vztah rodičů k dětem. V roce 1991 zdravotní stav pohled na povinnosti rodičů vůči dětem

23 Jak dokazuje Bonferroniho test.

24 Přesné znění otázky bylo: „Když zvážíte všechny okolnosti, jak byste popsal(a) svůj současný zdravotní stav? Řekl(a) byste, že je: velmi dobrý, dobrý, ucházející, špatný, velmi špatný?“ Pro analytické účely byla proměnná trichotomizována na varianty dobrý, ucházející a špatný.

25 Rozdíl mezi muži a ženami je statisticky významný (v roce 1991 Sig. $=0,03$, v roce 2008 Sig. $=0,02)$.

26 Asociace mezi subjektivním zdravotním stavem a úctou k rodičům je však slabá. Cramerovo V mělo v roce 2008 hodnotu 0,17 pro ženy a 0,13 pro muže, kdy se zhoršujícím se zdravotním stavem respondent častěji volí, že rodiče musíme ctít.

27 Vzájemná asociace úcty $\mathrm{k}$ rodičům a subjektivního zdravotního stavu dle Cramerova V byla v roce 1991 u mužů 0,02 a u žen 0,08 . 
neovlivňoval a nelišil se ani pohled mužů a žen. ${ }^{28} \mathrm{O}$ povinnosti rodičů udělat pro své děti vše bylo přesvědčeno $72 \%$ seniorské populace. V roce 2008 už je však tento postoj zdravotním stavem ovlivňován. ${ }^{29}$ Senioři-muži s dobrým zdravím jsou přesvědčeni o povinnosti rodičů udělat vše pro své děti v 51 \%, ti se špatným zdravím však v 83 \%. U seniorek s dobrým zdravotním stavem je to $48 \%$ a se špatným $58 \%$. Horší zdravotní stav tedy v současnosti přispívá ke zvýšení normativní mezigenerační solidarity v seniorské populaci. Jde přitom o nový jev, který se na začátku devadesátých let nevyskytoval.

V české populaci došlo od začátku devadesátých let k mírnému poklesu normativní mezigenerační solidarity. Pokleslo jak přesvědčení o odpovědnosti rodičů k dětem, tak dětí $\mathrm{k}$ rodičům. Ještě významnější proměnou však je větší diverzifikace postojů podle věku i genderu. Ženy si stále udržují vyšší míru mezigenerační solidarity a tento rozdíl se do současnosti ještě prohloubil. Stejně tak se prohloubily rozdíly mezi jednotlivými věkovými skupinami. Čeští senioři a seniorky přitom vykazují mírně vyšší mezigenerační solidaritu než mladší populace. Tento fakt by mohl do budoucna přinést větší míru konfliktů v mezigeneračních vztazích. Jak však ukazuje teorie contingent care (Eggebeen a Davey 1998), pomoc je vyjednávána a poskytována až v př́padě její potřeby. Generační rozrůznění norem ještě nemusí znamenat, že senioři zůstanou bez pomoci rodiny, tedy že se rodina v př́padě potřeby pomoci nemobilizuje. Výzkum Finch a Mason (1993) z britského prostředí ukázal, že pomoc v rámci rodiny je spíše vyjednávána, než že by její míra a podoba byla automaticky dána jen na základě existence př́buzenského vztahu. Je tedy závislá na vztazích konkrétních jedinců i potřebě podpory.

\section{Vztah mezi úctou k rodičům a dalšími rodinnými hodnotami}

Přirozeně mne zajímalo, jaké sociodemografické faktory a jaké postoje v současnosti ovlivňují vztah dětí k rodičům, tedy to, zda je respondent přesvědčen, že rodiče musíme ctít, nebo ne. Pomocí binární logistické regrese jsem se proto pokusila odhadnout model, ve kterém je závisle proměnnou úcta k rodičům. Nalezení nezávisle proměnných, které by byly pro model optimální, nebylo úplně snadné. Vliv prokázaly proměnné věk, pohlaví, velikost obce a oblast bydliště. Ze sociodemografických charakteristik z výsledného modelu vypadly proměnné vzdělání, počet dětí i rodinný stav. Z proměnných odkazujících $\mathrm{k}$ hodnotám se nepodařilo prokázat vliv důležitosti rodiny v životě (protože de facto všichni považují rodinu za důležitou), pocitu kontroly nad životem ani subjektivního zdravotního stavu. ${ }^{30}$ Ve finálním modelu zůstala důležitost náboženství v životě, vztah rodičů k dětem a povinnost dětí

Vzájemná asociace povinnosti rodičů k dětem a subjektivního zdravotního stavu byla dle Cramerova $\mathrm{V}$ v roce 19910,07 u mužů i u žen.

29 Vzájemná asociace povinnosti rodičů k dětem a subjektivního zdravotního stavu byla dle Cramerova $\mathrm{V}$ v roce 20080,20 u mužů a 0,15 u žen.

30 Subjektivní zdravotní stav však vliv na mezigenerační solidaritu přesto má, ovšem pouze v seniorské populaci. U seniorů je patrný jasný nárůst mezigenerační solidarity s pocitem špatného subjektivního zdravotního stavu. 
vůči rodičům. Nagelkerkeho pseudoR ${ }^{2}$ výsledného modelu nabývá hodnoty 0,256 a model závisle proměnnou predikuje správně u $72 \%$ respondentů.

Jak už jsem zjistila výše, pohlaví má velký vliv na to, zda je respondent přesvědčen o nutnosti ctít rodiče či ne. Ženy mají 1,3krát větší šanci (viz tabulku 2), že budou přesvědčeny o nutnosti ctít rodiče než muži. Významný vliv má také velikost obce, kdy se šance na bezvýhradnou úctu k rodičům snižuje se vzrůstající velikostí bydliště. Roli však nehraje jen velikost bydliště, ale i oblast, kde respondent žije, tedy zda jde o Čechy nebo Moravu. Bydliště na Moravě zvyšuje šanci na úctu k rodičům 3,9krát oproti bydlišti v Čechách. Stejně tak zvyšuje šanci, že respondent bude preferovat úctu k rodičům, souhlas s výroky, že rodiče musí pro své děti udělat vše a že děti se musí postarat o dlouhodobě nemocného rodiče i na úkor osobního blaha. Roli hraje také víra respondenta: ti, kteří považují náboženství ve svém životě za důležité, mají 1,9krát větší šanci, že budou ctít rodiče za všech okolností. Jak už jsem však ukázala výše, náboženství je důležité jen pro malou část české populace.

Tabulka 2: Koeficienty výsledného modelu binární logistické regrese

\begin{tabular}{|c|c|c|c|c|c|c|}
\hline & & B & Std. Error & Wald & Sig. & $\operatorname{Exp}(B)$ \\
\hline & konstanta & 0,204 & 0,543 & 0,141 & 0,707 & 1,226 \\
\hline \multicolumn{7}{|c|}{ sociodemografické charakteristiky } \\
\hline věk & & 0,017 & 0,004 & 22,995 & 0,000 & 1,017 \\
\hline pohlaví (0-muž, 1-žena) & & 0,269 & 0,127 & 4,487 & 0,034 & 1,308 \\
\hline \multirow[t]{4}{*}{ velikost obce } & obec 100000 a více obyvatel & & & referenční & & \\
\hline & obec do 4900 obyvatel & $-1,448$ & 0,474 & 9,338 & 0,002 & 0,235 \\
\hline & obec 5 000-19999 & $-1,121$ & 0,353 & 10,080 & 0,001 & 0,326 \\
\hline & obec 20 000-99999 & $-0,513$ & 0,239 & 4,612 & 0,032 & 0,599 \\
\hline Čechy (0) / Morava (1) & & 1,352 & 0,302 & 20,009 & 0,000 & 3,867 \\
\hline \multicolumn{2}{|c|}{ interakce velikosti obce a oblasti (Čechy nebo Morava) } & $-0,443$ & 0,107 & 17,166 & 0,000 & 0,642 \\
\hline \multicolumn{7}{|l|}{ hodnoty a postoje } \\
\hline \multirow[t]{3}{*}{ vztah rodičů k dětem } & $\begin{array}{l}\text { rodiče mají vlastní život a nemusí } \\
\text { se obětovat ve prospěch dětí }\end{array}$ & & & referenční & & \\
\hline & $\begin{array}{l}\text { povinností rodičů je udělat pro } \\
\text { děti to nejlepší }\end{array}$ & 1,026 & 0,157 & 42,716 & 0,000 & 2,791 \\
\hline & ani jeden z výroků & 0,523 & 0,202 & 6,672 & 0,010 & 1,686 \\
\hline \multirow[t]{3}{*}{$\begin{array}{l}\text { povinnost dětí } \\
\text { k rodičům }\end{array}$} & děti mají vlastní život & & & referenční & & \\
\hline & $\begin{array}{l}\text { děti povinnost dlouhodobé } \\
\text { péče o rodiče i na úkor osobního } \\
\text { blaha }\end{array}$ & 0,996 & 0,155 & 41,154 & 0,000 & 2,709 \\
\hline & ani jeden z výroků & 0,539 & 0,210 & 6,575 & 0,010 & 1,715 \\
\hline \multicolumn{2}{|c|}{ důležitost náboženství v životě (0 - nedůležité, 1 - důležité) } & 0,632 & 0,183 & 11,964 & 0,001 & 1,881 \\
\hline
\end{tabular}

Pramen: EVS 2008, vlastní výpočet.

Poznámka: Závisle proměnnou je dichotomie úcty k rodičům. 
Aplikace výsledného modelu na předchozí vlny výzkumu se ukázala jako nevhodná. Jak už naznačily deskriptivní statistiky výše, vliv pohlaví, věku a dalších faktorů se v jednotlivých výzkumných vlnách výrazně proměnil. Optimální modely vhodné pro jednotlivé vlny výzkumu by tak obsahovaly různé nezávisle proměnné a užitečnost takového srovnání by byla velmi omezená. Některé použité proměnné byly navíc dotazovány pouze v roce 2008 . $\mathrm{Z}$ tohoto důvodu jsem se soustředila pouze na nalezení faktorů ovlivňujících zvolenou složku normativní mezigenerační solidarity v současnosti, to znamená, že jsem pracovala s daty z roku 2008. Prokázala jsem přitom velký vliv pohlaví, věku, bydliště i náboženského cítění respondenta.

\section{Srovnání České republiky s dalšími evropskými zeměmi}

Až dosud jsem se věnovala pouze situaci v České republice a zjistila jsem, že míra normativní solidarity se v jednotlivých generacích liší a především se celkově snižuje. Vyvstává tedy otázka, zda je situace v České republice nějak výjimečná a zda se tedy máme obávat mezigeneračních střetů. Pro zodpovězení těchto otázek jsem srovnala míru normativní solidarity v evropských zemích. Vzhledem k tomu, že mi šlo pouze o zjištění pozice České republiky v rámci evropských zemí, věnovala jsem se pouze celkové míre normativní solidarity v jednotlivých evropských zemích bez ohledu na věk či pohlaví respondentů. ${ }^{31}$ Do analýzy vstoupily otázky vztahu rodičů $\mathrm{k}$ dětem i dětí k rodičům, stejně jako důležitost rodiny $\mathrm{v}$ životě respondenta.

Zjistila jsem, že rodina se mezi Evropany těší velké důležitosti. Za velmi důležitou či důležitou ji v jednotlivých zemích považuje 95-100\% obyvatel. Největší význam má pro obyvatele Kypru, Malty a Černé Hory, kde ji za velmi důležitou považuje 92-93 \% obyvatel. Naopak v pobaltských zemích ji za velmi důležitou považují méně než tři čtvrtiny respondentů, ostatní pak za důležitou. Ani v těchto zemích však nemůžeme na základě odpovědí respondentů pochybovat o zásadním významu rodiny v životě. V otázce, zda je nutné rodiče ctít, i když si to nezaslouží, se postoje v jednotlivých zemích liší výrazněji (viz graf 3). Zatímco na Ukrajině a Maltě odpovídá na otázku kladně více než $90 \%$ obyvatel, v Dánsku a Nizozemsku souhlasí méně než $40 \%$. Postoj k úctě k rodičům se tak výrazně liší mezi zeměmi východní a severní Evropy. Česká republika se přitom se 64\% souhlasem zařadila blíže zemím severským. Je tedy patrné, že postoj českých občanů k povinnosti ctít rodiče není v Evropě nijak výjimečný.

$\mathrm{V}$ roce 2008 se vztahu dětí k rodičům ve výzkumu EVS věnovala ještě další otázka a to, zda je povinností dítěte postarat se nemocného rodiče (viz graf 4 ). ${ }^{32} \mathrm{I} v$ tomto prípadě

31 Nabízí se také možnost provést podrobnější analýzu, která by se věnovala i variabilitě dle věku a pohlaví pro vybrané země jednotlivých regionů (tj. Skandinávie, západní Evropa, jižní Evropa a východní Evropa). Jak však ukázala deskriptivní analýza níže, země zastoupené v jednotlivých regionech jsou značně heterogenní. Analýza na úrovni regionů by tedy nebyla smysluplná. Důkladnější analýza postojů obyvatel jednotlivých zemí dle věku a pohlaví je však dobrým námětem na další zkoumání, pro které však v rámci tohoto textu není dostatek prostoru.

32 Přesné znění otázky bylo: „Co si myslíte o následujících výrocích? Souhlasíte s nimi, nebo nesouhlasíte? ...Když je rodič vážně nemocen nebo je křehkého zdraví, je především povinností 
se ukázal výrazný rozdíl mezi zeměmi východní a severní Evropy, kdy na Ukrajině je souhlas s povinností dětí postarat se o nemocné rodiče nejsilnější a v Dánsku a Finsku naopak nejslabší. Kromě Dánska a Finska však ve všech ostatních zemích převažuje různě intenzivní souhlas s touto povinností. Méně než $20 \%$ Dánů a Finů je také přesvědčeno o povinnosti dospělých dětí poskytnou rodičům dlouhodobou péči (viz graf 5). ${ }^{33}$ Jejich postoj k odpovědnosti dětí k rodičům se tedy zdá poměrně konzistentní. U ostatních Evropanů je přesvědčení o existenci určitého závazku dětí vůči rodičům silnější. Stejně jako u předchozích otázek je patrná výrazná postojová diferenciace, a to mezi zeměmi východo- či jihoevropskými a západo- a severoevropskými. Češi se svým postojem blíží spíše k zemím západoevropským.

Graf 3: Úcta dětí k rodičưm: Podíl respondentů souhlasících s výrokem, že rodiče musíme ctít, i když si to nezaslouží; dle zemí ( $\vee \%$ )

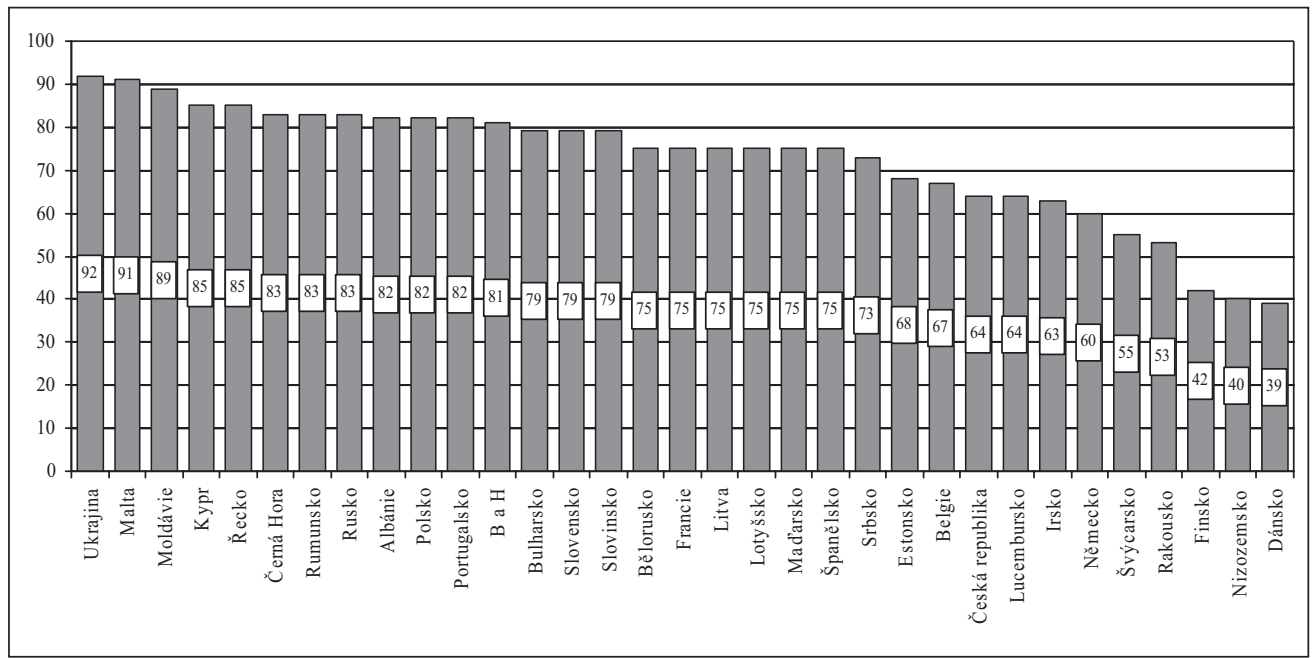

Zdroj: EVS 2008, vlastní výpočet.

dospělého dítěte postarat se o něj.“ Odpověd’ respondenti volili na pětibodové škále (rozhodně souhlasím - rozhodně nesouhlasím).

33 I tato otázka byla v ČR dotazována pouze v roce 2008. Přesné znění otázky bylo: „Který z následujících výroků nejlépe vyjadřuje Váš názor na povinnosti dospělých dětí vůči rodičům v situaci, kdy jejich rodiče potřebují dlouhodobou péči? 1 - Dospělé děti mají povinnost poskytovat svým rodičům dlouhodobou péči, byt' i na úkor svého osobního blaha. 2 - Dospělé děti mají svůj vlastní život a nikdo by po nich neměl žádat, aby se obětovaly ve prospěch svých rodičů." Respondenti také mohli spontánně odpovědět, že nesouhlasí ani s jedním z výroků. 
Graf 4: Názor na povinnost dítěte postarat se o nemocného rodiče, prưměr ze škály 1-5 (1 = rozhodně souhlasím, 5 = rozhodně nesouhlasím)

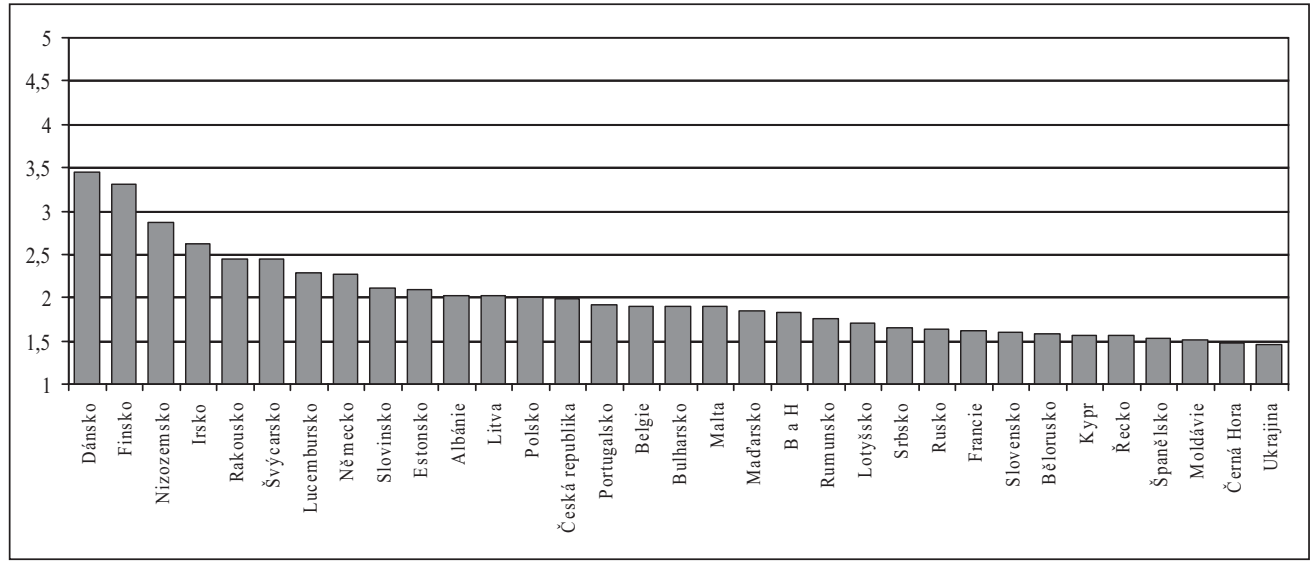

Zdroj: EVS 2008, vlastní výpočet.

Graf 5: Názor na povinnost dospělých dětí vưči rodičům v situaci, kdy jejich rodiče potřebují dlouhodobou péči ( $\vee \%)$

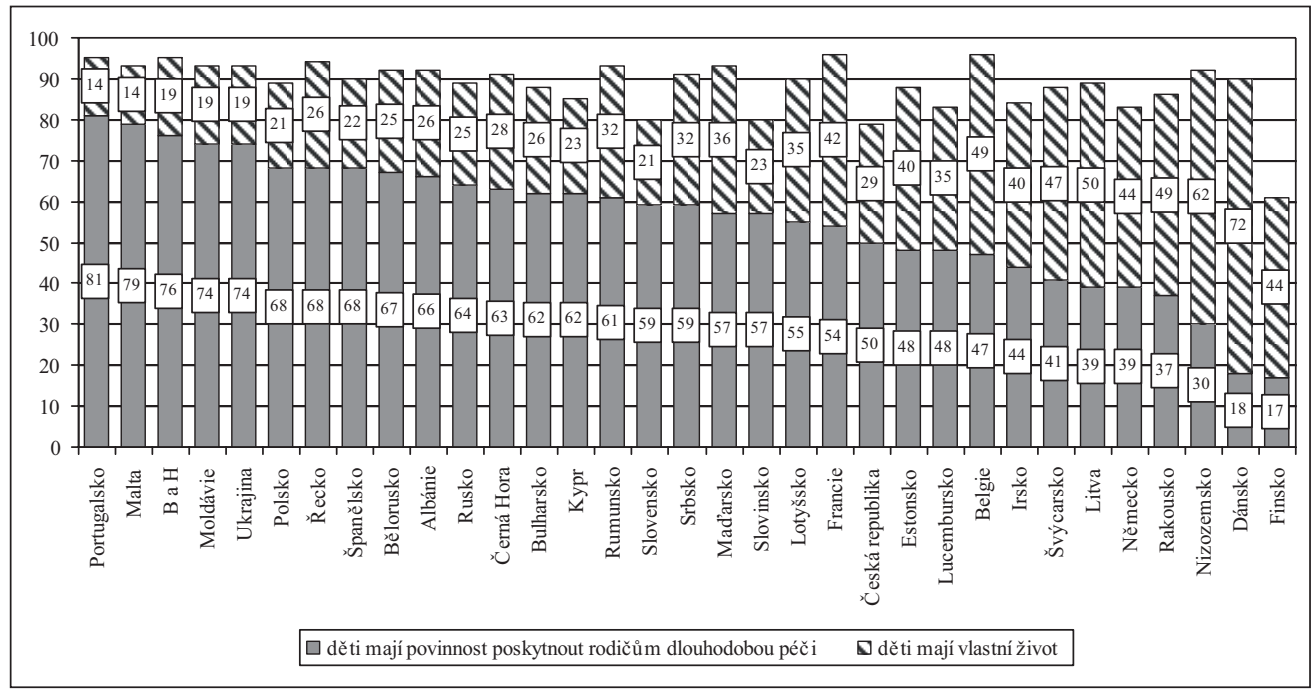

Zdroj: EVS 2008.

Poznámka: Dopočet do 100\% tvoři v grafu vynechaná kategorie "ani jeden z výrokư".

Poslední otázka, která vstoupila do srovnání mezigenerační solidarity Evropanů, se zaměřila na opačný vztah, tedy na odpovědnost rodičů vůči dětem. Jak je patrné z grafu 6 , 
nejsilněji jsou o povinnosti rodičů udělat pro své děti vše přesvědčeni obyvatelé Malty, kde je souhlas s výrokem více než $90 \%$. Ve většině ostatních států souhlasí s výrokem alespoň tři čtvrtiny populace. Naopak naprosto se vymyká Litva, kde souhlasilo jen $38 \%$ respondentů. Nízký souhlas je však patrný i v České republice (54\%). V této otázce je tedy postoj české populace odlišný od většiny Evropy, je to však odlišnost jediná, v ostatních zkoumaných dimenzích normativní solidarity se český postoj od postojů většiny Evropanů neodlišuje.

Graf 6: Názor na odpovědnost rodičů vưči dětem v evropských zemích (v \%)

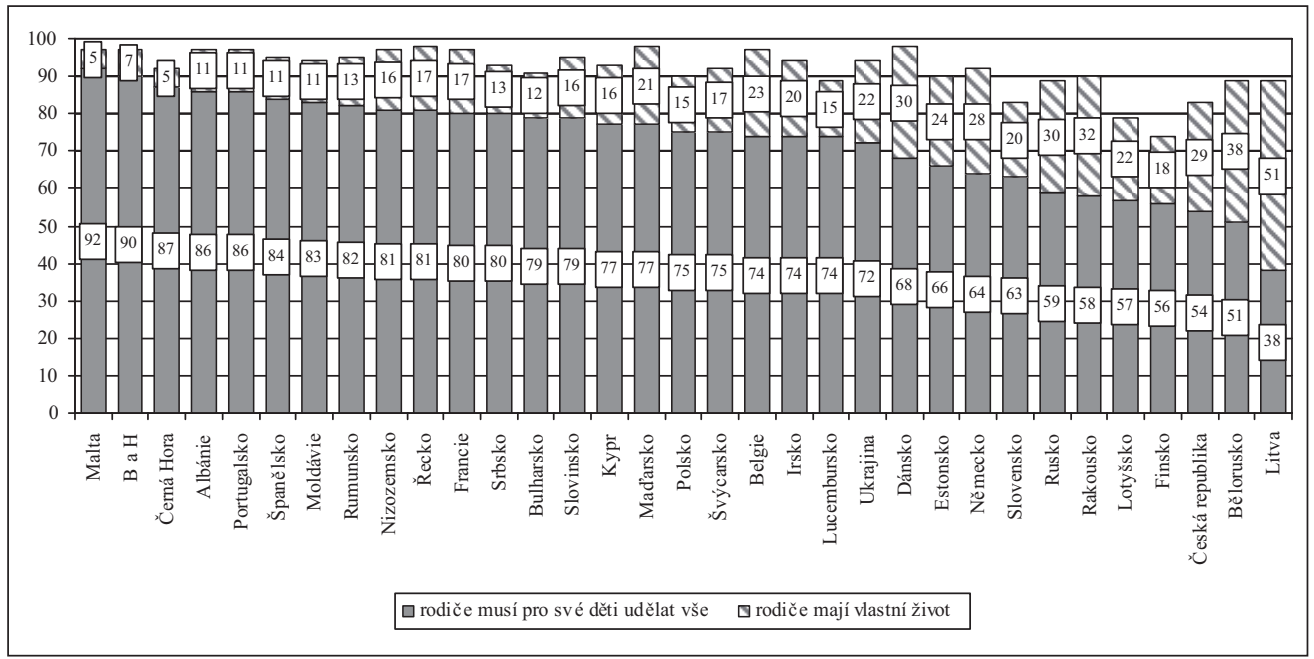

Zdroj: EVS 2008, vlastní výpočet.

Poznámka: Dopočet do 100\% tvoři v grafu vynechaná kategorie „ani jeden z výrokư“.

Všichni Evropané, jejichž vzorky máme zatím k dispozici, se tedy shodují na velké důležitosti rodiny ve vlastním životě, přesvědčení o odpovědnosti a závazku rodičů $\mathrm{k}$ dětem a dětí $\mathrm{k}$ rodičům je však $\mathrm{v}$ jednotlivých zemích různě silné. Předchozí analýza už naznačila, že z hlediska normativní solidarity jsou si blízké země severní Evropy. Určitou podobnost je možné vysledovat i v zemích jižní a východní Evropy, na druhou stranu jsou však mezi nimi patrné i značné odlišnosti. Stejně tak není možné mluvit např́klad ani o shodných postojích obyvatel Beneluxu, mezi Nizozemím, Belgií a Lucemburskem jsou naopak patrné značné rozdíly. Celkové srovnání nám umožňuje hierarchická shluková analýza. ${ }^{34}$

34 Vzhledem k př́liš velkému objemu dat byla hierarchická shluková analýza aplikována na agregovaná data s průměrnými hodnotami pro jednotlivé země. Do shlukové analýzy vstoupily pouze země, kde bylo dotazováno všech pět použitých proměnných. Ze srovnání tak vypadly např́íklad Itálie či Švédsko. Kromě výše zmíněných proměnných bylo do analýzy zahrnuto HDP země a podíl osob starších 65 let v populaci. 
Graf 7: Dendrogram normativní solidarity v evropských zemích v roce 2008

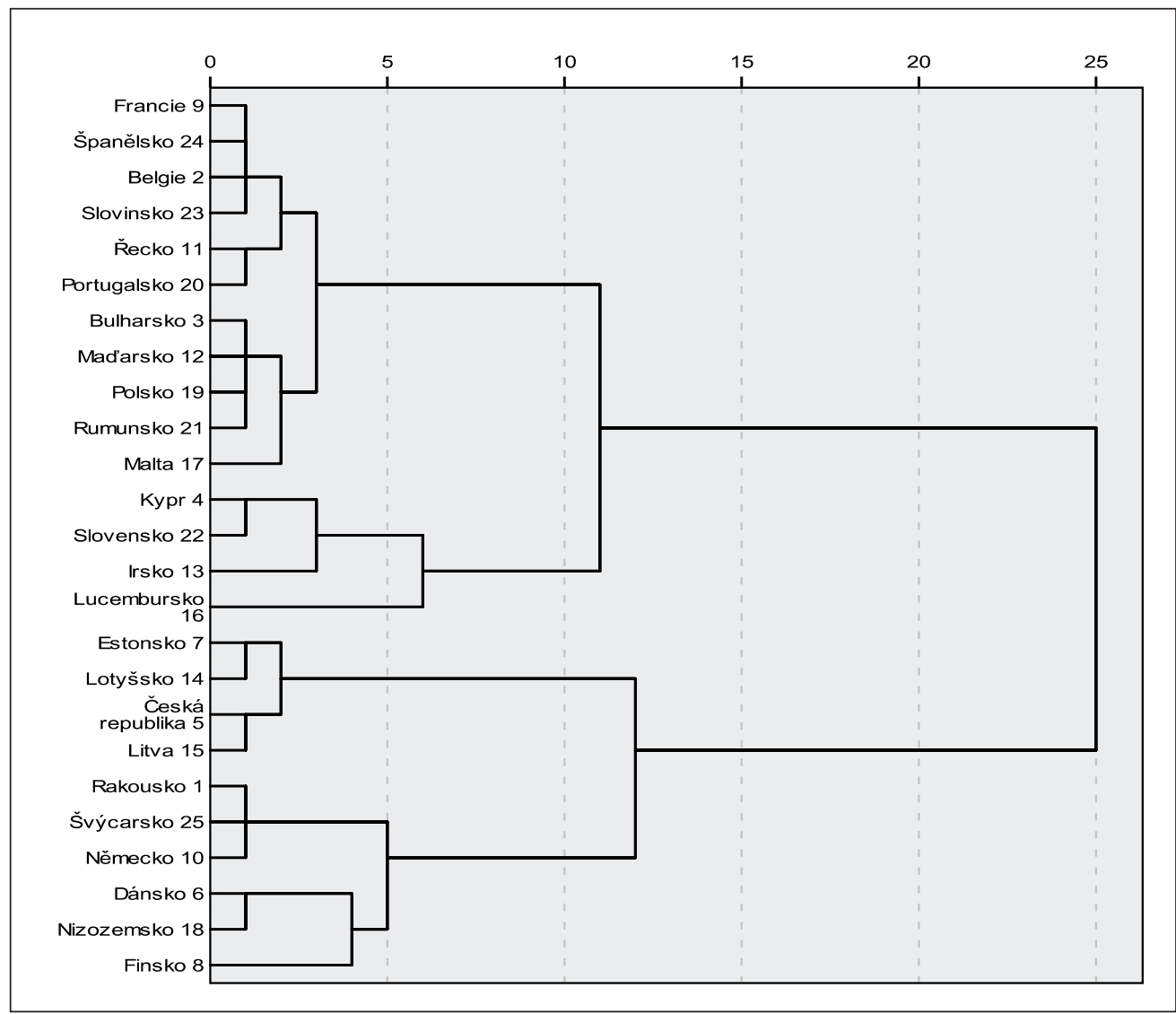

Zdroj: EVS 2008 a Eurostat 2010, vlastní výpočet; použita Wardova metoda shlukování, standardizace pomocí směrodatných odchylek.

Poznámka: Dendrogram shlukuje země na základě prưměrných hodnot proměnných v jednotlivých zemích.

Z výsledného dendrogramu (viz graf 7) je patrné, že Česká republika není mezi evropskými zeměmi nijak výjimečná. Nejblíže má k pobaltským státům, zejména k Litvě. Relativně blízko však má i k německým jazykovým oblastem (Německu, Rakousku, Švýcarsku) a skandinávským zemím. Dále je patrné rozdělení evropských zemí na dvě velké skupiny, tak jak už to naznačila předchozí analýza. Dělení nejde po východo-západní Hajnalově linii, ${ }^{35}$ ale zdá se, že se drží spíše severo-jižního směru. Ukazují se tedy výrazné rozdíly mezi zeměmi

Demograf John Hajnal rozdělil na základě analýzy manželského a reprodukčního chování Evropu podle hranice Petrohrad - Terst. Západoevropský typ rodiny (někdy také označovaný jako severozápadní) se vyznačuje relativně pozdním věkem sňatku, nukleární a neolokální rodinou. Pro východoevropský typ je charakteristický nižší věk sňatku a klanový typ rodiny (Možný 1999). 
severní a střední Evropy na jedné straně a Evropy jižní a východní na straně druhé. Z tohoto pohledu spadá Česká republika do skupiny severských a středoevropských států, tedy zemí s významnou rolí státu při zajištění péče a podpory, v porovnání se zeměmi jihoevropskými, spoléhajícími se více na pomoc rodiny. Spoléhání se na stát v oblasti sociální pomoci je ostatně v české populaci velmi výrazné, což ukazují mnohé výzkumy (např́ílad Vidovićová a Rabušic 2003). Ukazují však také, že čeští senioři obecně nejsou ohroženi exkluzí a odsunuti na okraj, ale že rodina je připravena jim v prŕpadě potřeby poskytnout péči (Sýkorová 2007). Jak však poznamenávají Vidovićová a Rabušic (2003), rodina se k pomoci mobilizuje, ale očekává pomoc institucí, pokud pro ně začne být péče neúnosná.

Srovnáním s dalšími evropskými zeměmi jsme se přesvědčili, že přestože česká populace změnila svůj postoj k mezigenerační solidaritě, není její postoj v Evropě ojedinělý, a není tedy třeba, aby v nás vzbuzoval př́lišné obavy.

\section{Závěr}

$\mathrm{V}$ této stati jsem se věnovala vztahům rodičů a dětí $\mathrm{z}$ hlediska hodnot a norem. Soustředila jsem se tedy na dimenzi mezigenerační solidarity označovanou jako normativní. Vzhledem k tomu, že transformace společnosti se neobejde bez proměny jejích hodnot, mne zajímalo, jak se proměnila mezigenerační solidarita české společnosti od počátku transformace $\mathrm{v}$ devadesátých letech do současnosti. Výsledky ukazují, že míra normativní mezigenerační solidarity v české společnosti mírně poklesla, stále však zůstává vysoká. Především však došlo k hodnotovému rozrůznění podle věku a genderu. Ženy jsou považovány za nositelky mezigenerační solidarity v rodině. Také v tomto výzkumu prokázaly vyšší míru solidarity než muži. Rozdíly mezi oběma gendery se navíc stále zvyšují, což je překvapivé a otevírá to možnost dalšího bádání. Soustředila jsem se především na srovnání českých seniorů s mladší populací. I když senioři vykazují vyšší míru mezigenerační solidarity než mladší jedinci, není rozdíl nijak fatální. Navíc i u nich dochází k postupnému poklesu.

V socialistickém období měly mezigenerační vztahy velký význam. Širší rodina byla důležitá pro zajištění životní úrovně a podpora plynoucí od starší generace ke generacím mladším byla značná. Rodičovství pak bylo chápáno jako celoživotní závazek. V současnosti se však místo o poklesu významu mezigeneračních vztahů začíná mluvit o nárůstu jejich důležitosti. Důvodem je značná nestabilita rodiny a celkové rozrůznění životních forem. Podstatný vliv má také stárnutí populace. Nárůst počtu seniorů ve společnosti nám vnucuje otázku, zda společnost péči o ně zvládne. Debaty se proto soustřed’ují na úlohu rodiny při naplňování potřeb nesoběstačných jedinců. Otázkou však zůstává, zda bude současnál budoucí rodina ochotna tuto odpovědnost príijmout. Pokles porodnosti znamenal totiž i úbytek potenciálních pečovatelů. S prodloužením doby soužití více generací došlo i k úbytku příslušníků jedné generace. Rodinné solidaritě a podpoře je sice $\mathrm{v}$ českém prostředí věnovaná značná pozornost, badatelé se však soustřed'ují na afektivní a materiální dimenzi podpory. Zkoumá se intenzita mezigeneračního vztahu i obsah a objem praktické pomoci. Studie věnující se mezigenerační podpoře $\mathrm{z}$ hlediska hodnot a norem zatím chybí. Touto statí jsem se zmíněnou mezeru pokusila alespoň částečně vyplnit. 
Nezůstala jsem jen u popisu výsledků jednotlivých složek normativní solidarity, ale v další části jsem hledala faktory, které v současnosti ovlivňují úctu dětí k rodičủm, tedy jednu ze zkoumaných rodinných hodnot. Výsledný model binární logistické regrese ukazuje značný vliv pohlaví, věku a bydliště respondenta. Ale také náboženského cítění a dalších položek regulujících vztah rodičů a dětí. Model se však ukázal vhodný pouze pro nejnovější data a nebylo možné ho aplikovat na starší vlny výzkumu.

Nakonec mne zajímalo, jaké je z hlediska rodinných hodnot a rodinné odpovědnosti postavení České republiky mezi evropskými zeměmi. Hierarchická shluková analýza ukázala, že se velmi podobáme zemím, kterým jsme blízko bud’ geograficky, nebo svým ekonomickým a historickým vývojem. Nejblíže tak máme k pobaltským státům a sousednímu Rakousku a Německu. Naopak se značně odlišujeme od zemí jižní, ale i východní Evropy. Řadíme se tak mezi země, $v$ nichž velkou roli v péči o nesoběstačné jedince hrají instituce a jejich potřeby nezajišt'uje jen rodina. Tento výsledek je v souladu s dalšími výzkumy (za všechny např́klad Vidovićová a Rabušic 2003), které ukázaly, že rodina je ochotná poskytnout podporu, očekává však pomoc státu a institucí. Navíc, jak jsem ukázala, si rodina i přes všechny proměny, kterými prošla, ponechala velmi důležité místo v životě české populace.

\section{Literatura}

BENGTSON, Vern L. ; ROBERTS, Robert E. L. Intergenerational Solidarity in Aging Families : An example of Formal Theory Construction. Journal of Marriage and Family, 1991, roč. 53, č. 4, s. 856 - 870. ISSN 0022-2445.

BENGTSON, Vern L. Beyond the Nuclear Family : The Increasing Importance of Multucultural Bonds. Journal of Marriage and Family, 2001, roč. 63, č. 1, s. 1 - 16. ISSN 0022-2445.

BENGTSON, Vern L. ; PETER, Martin. Families and Intergenerational Relationships in Aging Societies : Comparing the United States with German-Speaking Countries. Zeitschrift für Gerontologie und Geriatrie, 2001, roč. 34, č. 3, $\quad$ s. $207-217$. ISSN 0948-6704.

Český statistický úruad. Last revision [online]. 2010, [cit. 2010-09-07]. Dostupné z: http://www.czso.cz/

EGGEBEEN, David J. ; DAVEY, Adam. Do Safety Nets Work? The Role of Anticipated Help in Time of Need. Journal of Marriage and the Family, 1998, roč. 60, č. 4, s. 939 - 950. ISSN 0022-2445.

Eurobarometr. Intergenerational solidarity. Analytical Report [online] 2009, [cit. 2010-08-15]. Dostupné z: http://ec.europa.eu/public_opinion/index_en.htm.

FINCH, Janet. Family Obligations and Social Change. Cambridge : Polity Press, 1989. 250 s. ISBN 978-0-745-60324-7.

FINCH, Janet ; MASON, Jennifer. Negotiating Family Responsibilities. London : Routledge, 1993. 240 s. ISBN 978-0-415-08407-9.

Van GAALEN, Ruben I. ; DYKSTRA, Pearl A. Solidarity and Conflict Between Adult Children and Parents : A Latent Class Analysis. Journal of Marriage and Family, 2006, roč. 68, č. 4, s. 947 - 960. ISSN 0022-2445.

HASMANOVÁ MARHÁNKOVÁ, Jaroslava. Proměny prarodičovství v kontextu představ aktivního stáŕí. In Sociologica-andragogica 2009. Problémy ohrožených skupin, mezigenerační vztahy. Olomouc : Univerzita Palackého, 2010, s. 11 - 26. ISSN 1803-0246.

JEŘÁBEK, Hynek. Rodinná péče o seniory jako ,práce z lásky : nové argumenty. Sociologický časopis, 2009 , roč. 45 , č. 2 , s. $243-265$. ISSN 0038-0288. 
Kvalita života ve stárí. Národni program připravy na stárnutí na obdobi 2008-2012. Praha : Ministerstvo práce a sociálních věcí, 2008.

LUESCHER, Kurt ; PILLEMER, Karl. Intergenerational Ambivalence : A New Approach to the Study of Parent-Child Relations in Later Life. Journal of Marriage and Family, 1998, roč. 60, č. 2, s. 413 - 425. ISSN 0022-2445.

MOŽNÝ, Ivo. Proč tak snadno? 1. vyd. Praha : Slon, 1991. 81 s. ISBN 80-901-0590-4.

MOŽNÝ, Ivo. Sociologie rodiny. 1. vyd. Praha : Sociologické nakladatelství, 1999. 251 s. ISBN 80-858-5075-3.

MOŽNÝ, Ivo [et al.] Mezigeneračni solidarita, výzkumná zpráva z mezinárodního srovnávacího výzkumu „Hodnota dětí a mezigenerační solidarita“. Praha : VÚPSV, 2004. 111 s.

Eurostat. Last revision. [online]. [cit. 2010-11-11]. Dostupné z http://epp.eurostat.ec.europa.eu/portal/ page/portal/eurostat/home/

PARSONS, Talcott ; BALES, Robert F. Family, Socialization and Interaction Process. Gloncoe : Free Press, 1955. $440 \mathrm{~s}$.

PŘIDALOVÁ, Marie. 2007. Mezi solidaritou a konfliktem: zkušenost pečujících dcer a synů. Sociální studia, roč. 4, č. 1-2, s. 217 - 234. ISSN 1214-813X.

RABUŠIC, Ladislav. Úvodem. Sociálni studia, 2001, č. 6, s. 9 - 15. ISSN 1214-813X.

RABUŠIC, Ladislav; HAMANOVÁ, Jana. Hodnoty a postoje v ČR 1991-2008 (pramenná publikace European Values Study). 1. vyd. Masarykova univerzita : Brno, 2009. 324 s. ISBN 978-80-210-4952-9.

ROSSER, Colin ; HARRIS, Christopher Ch. The Family and Social Change : A Study of Family and Kinship in South Wales Town. London : Routledge \& Kegan Paul, 1965.

SCHANS, Djamila ; KOMTER, Aafke. Ethnic Differences in Intergenerational Solidarity in the Netherlands. Journal of Aging Studies, 2010, roč. 24, č. 3, s. 194 - 203. ISSN 0890-4065.

STEIN, Catherine H. [et al.] "Because They're My Parents" : An Intergenerational Study of Felt Obligation and Parental Caregiving. Journal of Marriage and Family, 1998, roč. 60, č. 3, s. 611 - 622. ISSN 0022-2445.

SÝKOROVÁ, Dana. Rodina staršího středního věku v systému příbuzenské pomoci a podpory. Konceptuální rámce intergenerační rodinné solidarity s hlavním zřetelem na anglosaskou sociologickou produkci. Sociologický časopis, 1996, roč. 32, č. 1, s. 51 - 66. ISSN 0038-0288.

SÝKOROVÁ, Dana. Autonomie ve stáríi. Kapitoly z gerontosociologie. Praha : SLON, 2007. 285 s. ISBN 978-80-86429-62-5.

SÝKOROVÁ, Dana. Změna sociologické perspektivy aneb od nukleární rodiny k širší rodině. Sociálni studia, 2009, roč. 6, č. 4, s. 43 - 54. ISSN 1214-813X.

TOŠNEROVÁ, Tamara. Pocity a potřeby pečujicich o starši rodinné př́slušniky. Praha: Ambulance pro poruchy paměti, Ústav lékařské etiky 3. LF UK, 2001. ISBN 80-238-8001-2.

TOWNSEND, Peter. The Family Life of old People : An Inquiry in East London. London : Routledge \& Kegan Paul, 1957.

VIDOVIĆOVÁ, Lucie ; RABUŠIC, Ladislav. Senioři a opatření v oblasti stárnutí v pohledu české veřejnosti. Zpráva z empirického výzkumu. Praha : Výzkumný ústav práce a sociálních věcí [výzkumné zprávy], 2003. $67 \mathrm{~s}$.

VOHRALÍKOVÁ, Lenka ; RABUŠIC, Ladislav. Čeští senioři včera, dnes a zitra. 1. vyd. Praha : Výzkumný ústav práce a sociálních věcí-výzkumné centrum Brno [výzkumné zprávy], 2004. $90 \mathrm{~s}$.

WHO. Active Ageing : A Policy Framework. Geneva : World Health Organization, 2002. 59 s.

WILlMOTT, Peter ; YOUNG, Michael. Family and Class in a London Suburb. London : Routledge \& Kegan Paul, 1960. 


\section{Autorka}

je studentkou doktorského studijního programu sociologie na brněnské Fakultě sociálních studií Masarykovy univerzity. Kromě magisterského studia sociologie na téže fakultě je absolventkou historie Filozofické fakulty Masarykovy univerzity. Pedagogicky působí také na Janáčkově akademii múzických umění v Brně. Jejím výzkumným zájmem je problematika populačního stárnutí, hodnotových proměn seniorů a koncept aktivního stárnutí.

Kontakt:kfkv@seznam.cz 